Anja Verbičำ, Martin Šala², Marija Gorjanc ${ }^{1}$

${ }^{1}$ University of Ljubljana, Faculty of Natural Sciences and Engineering, Aškerčeva 12, SI-1000 Ljubljana, Slovenia

2National Institute of Chemistry, Hajdrihova 19, SI-1000 Ljubljana, Slovenia

\title{
The Influence of in situ Synthesis Parameters on the Formation of ZnO Nanoparticles and the UPF Value of Cotton Fabric
}

\author{
Vpliv parametrov sinteze in-situ na tvorbo nanodelcev $\mathrm{ZnO}$ in \\ vrednost UZF bombažne tkanine
}

Original Scientific Article/lzvirni znanstveni članek

Received/Prispelo 10-2018 • Accepted/Sprejeto 11-2018

\begin{abstract}
The aim of this research was to investigate different parameters of the in situ synthesis of ZnO nanoparticles on cotton in order to achieve a high ultraviolet protection factor (UPF). In the first part of the research the influence of different reducing agents $\left(\mathrm{Na}_{2} \mathrm{CO}_{3}, \mathrm{KOH}\right.$, and $\left.\mathrm{NaOH}\right)$ and their molar concentrations (0.1 $\mathrm{M}$ and $1 \mathrm{M}$ ) on the formation of $\mathrm{ZnO}$ nanoparticles and on the UPF values of cotton fabric were studied. The second part of the research was focused on the other parameters of in situ synthesis, such as the synthesis time ratio (time ratio between the treatment of the fabric in the precursor $\left(\mathrm{ZnCl}_{2}\right)$ and treatment after the reducing agent was added) and drying period duration after the in situ synthesis. Using UVNis spectroscopy, high UPF values (UPF 50+) were measured for cotton fabrics where in situ synthesis was performed using $\mathrm{NaOH}$ and $\mathrm{KOH}$, both at $1 \mathrm{M}$ molar concentration. Inductively coupled plasma mass spectrometry (ICP-MS) revealed a higher content of zinc on the fabric when $\mathrm{NaOH}$ was used. Scanning electron microscopy (SEM) showed that use of this reducing agent resulted in cotton fabric completely covered with small, round shaped nanoparticles. From the second part of the research, it was found that longer treatment times after the reducing agent was added produced functionalised cotton fabric with higher UPF values. The drying period duration after in situ synthesis did not significantly affect the UPF value of the fabric, but it did influence the morphology of the synthesised nanoparticles. With a longer drying time the nanoparticles were more rounded. The samples had poor wash fastness even after the first wash, which was found through low UPF values.

Keywords: in situ synthesis, nanoparticles, zinc oxide, UV radiation, cotton, UV protection
\end{abstract}

\section{Izvleček}

Namen raziskave je bil proučiti pogoje in situ sinteze nanodelcev cinkovega oksida na bombažni tkanini in doseči visok ultravijolični zaščitni faktor (UZF) funkcionalizirane tkanine. V prvem delu raziskave je bil proučevan vpliv vrste reducentov $\left(\mathrm{Na}_{2} \mathrm{CO}_{3}, \mathrm{KOH}, \mathrm{NaOH}\right)$ in njihove molarne koncentracije $(0,1 \mathrm{M}$ in $1 \mathrm{M})$ na oblikovanje nanodelcev $\mathrm{ZnO}$ na bombažni tkanini. $V$ drugem delu raziskave so bili proučevani še drugi dejavniki, kot so časovno razmerje sinteze (razmerje med časom obdelave tkanine $v$ prekurzorju in obdelave po dodatku reducenta) in čas sušenja po sintezi in situ. Visoke vrednosti UZF (50+), ki so bile določene na UVI Vis- spektrofotometru, so bile dosežene pri sintezi in situ ZnO-ND z uporabo NaOH in KOH v molarni koncentraciji 1M. Masna-spektrometrična analiza induktivno sklopljene plazme (ICP-MS) je potrdila večjo vsebnost cinka na tkanini, kjer je bil za sintezo in situ uporabljen NaOH. Iz posnetkov vrstične elektronske mikroskopije (SEM) je bilo razvidno, da so bili z uporabo NaOH pri sintezi in situ oblikovani ZnO nanodelci okrogle oblike,

Corresponding author/Korespondenčna avtorica:

Assist Prof dr. Marija Gorjanc

E-mail: marija.gorjanc@ntf.uni-lj.si
Tekstilec, 2018, 61(4), 280-288

DOI: 10.14502/Tekstilec2018.61.280-288 
ki so povsem oplaščili vlakna. V drugem delu raziskave je bilo ugotovljeno, da se nanodelci ZnO bolje oblikujejo in da ima funckionalizirana tkanina večje vrednosti UPF, ko je čas obdelave tkanine po dodatku reducenta daljši. Čas sušenja po sintezi in situ ni bistveno vplival na različne vrednosti UZF tkanine, je pa vplival na obliko nanodelcev, ki so se oblikovali na površini bombažnih vlaken. Z daljšim časom sušenja so se oblikovali nanodelci bolj pravilnih okroglih oblik. Funkcionalizirane tkanine niso imele dobre obstojnosti na pranje, kar je bilo ugotovljeno iz majhnih izmerjenih UPF-vrednosti funkcionaliziranih vzorcev bombažne tkanine po končanem pranju.

Ključne besede: sinteza in situ, nanodelci, cinkov oksid, UV-sevanje, bombaž, zaščita pred UV-sevanjem

\section{Introduction}

The modification of textile materials with nanoparticles has been the objective of several studies [1-7] aimed at producing finished fabrics with different performances. Zinc oxide $(\mathrm{ZnO})$ is an excellent candidate to be used for the fabrication of protective and functional textile materials due to its photocatalytic self-cleaning, antibacterial, UV-shielding and electrical properties, while having mechanical, thermal and chemical stability [8]. Furthermore, $\mathrm{ZnO}$ is also considered to be a biosafe material [9]. The deposition of $\mathrm{ZnO}$ nanoparticles onto textile materials is predominantly performed using pre-prepared $\mathrm{ZnO}$ nanoparticles (ex situ), because of their known size and shape and the ease of their application onto materials (i.e., dipping, impregnation or spraying). However, the pre-prepared $\mathrm{ZnO}$ nanoparticles have poor adsorption onto textiles. Moreover, the nanoparticles tend to form agglomerates on the surface of the fibre, which reduces the functional properties of textiles. These two particular drawbacks were reduced by using gaseous plasma as a textile pretreatment [10-12]. An alternative to deposition of ex situ prepared $\mathrm{ZnO}$ nanoparticles is their synthesis directly on material, or so called in situ (on site) synthesis. It was found that the functionalisation of textiles with in situ synthesised nanomaterials is very effective in enabling a rather uniform distribution of nanoparticles, as well as their good adsorption and adhesion, therefore providing durable protective properties of fabrics [8]. In the field of in situ synthesis of $\mathrm{ZnO}$ on textile materials, few studies have been published [13-19]. Researchers have achieved good photocatalytic $[17,19]$, UV protective $[13,16$, $18]$, and antimicrobial $[15,17,18]$ properties on cotton fabrics, and permanent hydrophilic surface, lower yellowing and increased tensile strength of wool [14]. The functionalisation of cotton with in situ synthesised $\mathrm{ZnO}$ nanoparticles included the immersion of fabric in a Zn-acetate $[13,15]$ or $\mathrm{Zn}$ nitrate solution [16-19] and the addition of a reducing agent $(\mathrm{NaOH})$. The reaction that involves the formation of $\mathrm{ZnO}$ nanoparticles from $\mathrm{Zn}$-salts includes two main steps [20]. The first step is nucleation (generation of $\mathrm{ZnO}$ nuclei), and the second is growth ( $\mathrm{ZnO}$ crystal growth). After adding an alkali to the $\mathrm{Zn}$-salt, $\mathrm{Zn}(\mathrm{OH})_{2}$ particles form. Then, $\mathrm{Zn}(\mathrm{OH})_{2}$ precipitates, and upon the appropriate hydrothermal conditions, dissociates into $\mathrm{Zn}^{2+}$ and $\mathrm{OH}^{-}$; and when the ion formation exceeds a critical value, which is necessary for the formation of $\mathrm{ZnO}$ crystals, $\mathrm{ZnO}$ begins to nucleate and crystal growth begins. In the literature on the topic of the synthesis of $\mathrm{ZnO}$ on textiles we found some papers that included the word "in situ" in their title; however from their content it is clear that the process is not truly in situ synthesis but rather a seeding method [21-23]. In these papers, nanoparticles are formed in the bath and after the synthesis, the fabric is immersed in the bath for few hours (from 8 to 24 hours), at temperatures from 80 to $130^{\circ} \mathrm{C}$, to allow seeding of the nuclei and further growth of $\mathrm{ZnO}$ nanoparticles on the textile material. Even though the results of these studies are positive (textile substrates had a self-cleaning photocatalytic capacity, increased hydrophilicity and increased protection against UV radiation), the process is far from suitable for industrial application. Even more importantly, the synthesis is time-consuming and is performed at a high temperature. The aim of our research was to study how different parameters of in situ synthesis, such as the concentration of the reducing agent, synthesis time and drying time, influence the formation of $\mathrm{ZnO}$ nanoparticles on cotton fabric and affect the UV protection factor of the functionalised fabric. 


\section{Experimental}

\subsection{Material}

Chemically bleached and mercerized cotton fabric (Tekstina tekstilna industrija Ajdovščina d. o. o.), zinc chloride $\left(\mathrm{ZnCl}_{2}\right.$, Honeywell), sodium carbonate $\left(\mathrm{Na}_{2} \mathrm{CO}_{3}\right.$, Sigma Aldrich), potassium hydroxide (KOH, Grammol), sodium hydroxide $(\mathrm{NaOH}$, Sigma Aldrich) were used in the research.

\subsection{In situ synthesis process}

In situ synthesis was performed at room temperature and a liquor ratio (LR) $1: 100$. The molarity of the precursor $\mathrm{ZnCl}_{2}$ was the same for all samples $(0.1 \mathrm{M})$, while the molarity of the reducing agent $\left(\mathrm{Na}_{2} \mathrm{CO}_{3}\right.$, $\mathrm{KOH}$, and $\mathrm{NaOH}$ ) was $0.1 \mathrm{M}$ and $1 \mathrm{M}$. The in situ synthesis process consisted of treating the cotton sample in precursor solution for a period of time at constant magnetic stirring (for 10, 20, 30 minutes), treating the sample after adding the reducing agent dropwise to the precursor solution for 10, 20, 30, 60 and 120 minutes, adjusting the drying period duration at $100{ }^{\circ} \mathrm{C}$ (for $10,30,60,120,240$ minutes), rinsing the sample with distilled water, wringing and finally drying the sample at $100{ }^{\circ} \mathrm{C}$ for 5 minutes.

\subsection{Durability to washing}

Samples were washed in laboratory apparatus Gyrowash 815 (James Heal, Great Britain) in accordance with EN ISO 105-C06 standard. The wash bath contained $4 \mathrm{~g} / \mathrm{l} \mathrm{ECE}$ phosphate reference detergent $\mathrm{B}$, the bath volume was $150 \mathrm{ml}$, the temperature of washing was $40{ }^{\circ} \mathrm{C}$ and the washing lasted for 45 minutes. Samples were washed without stainless steel globules which equals to 1 domestic washing and with added 10 stainless steel globules to perform washing equal to 5 domestic washings.

\subsection{Analytical methods}

\section{Ultraviolet Protection Factor}

The ultraviolet protection factor (UPF) of the untreated and functionalized fabric samples was determined according to the AATCC TM 183 standard and measurements were performed using a Varian CARY 1E UV/VIS spectrophotometer (Varian, Australia) containing a DRA-CA-301 integration sphere and Solar Screen software. The transmission of the ultraviolet radiation through the samples was measured in the spectral range between 280 and $400 \mathrm{~nm}$, and the average transmittance $(\mathrm{T})$ values with the wavelengths between 315 and $400 \mathrm{~nm}$ (UV-A), 280 and $315 \mathrm{~nm}$ (UV-B) and 280 and $400 \mathrm{~nm}$ (UV-R) were determined from the measurements. UPF was calculated according to the following equation:

$U P F=\frac{\sum_{\lambda=280}^{400} E_{\lambda} \times S_{\lambda} \times \Delta \lambda}{\sum_{\lambda=280}^{400} E_{\lambda} \times S_{\lambda} \times T_{\lambda} \times \Delta \lambda}$

where $E_{\lambda}$ is the relative erythermal spectral effectiveness, $S_{\lambda}$ is the solar spectral irradiance, $T_{\lambda}$ is the spectral transmittance of the specimen, and $\Delta \lambda$ is the measured wavelength interval in $\mathrm{nm}$. The UPF rating and UVR protection categories were determined from the calculated UPF values according to the Australian/New Zealand Standard: Sun protective clothing - Evaluation and classification. The Australian/New Zealand Standard (AS/NZ 4399: 1996) defines criteria for assessing the UV protective effectiveness of textiles and evaluation for labelling textile products with a protective function. The standard classifies textile products into three categories of protection, namely, excellent, very good and good protection [24]. The values are in the range of 15 to 50 and the higher the value, the better the protection.

\section{Scanning electron microscopy (SEM)}

The morphology of nanoparticles on the cotton fibres was observed by SEM JSM-6060 LV (JEOL, Japan). Prior to the SEM analysis, samples were coated with a layer of gold to ensure sufficient electrical conductivity. SEM micrographs were taken at 1500x magnification.

\section{Inductively coupled plasma mass spectroscopy (ICP-MS)}

$\mathrm{ZnO}$-functionalised cotton samples were analysed using mass spectrometry with inductive coupled plasma after microwave decomposition. Prior to ICP-MS analysis, each sample was weighted (approximately $100 \mathrm{mg}$ ) and digested using a microwave-assisted digestion system (CEM MDS-2000) in a solution of $7 \mathrm{ml} \mathrm{nitric} \mathrm{acid} \mathrm{and} 2 \mathrm{ml}$ hydrogen peroxide. The digested samples were cooled to room temperature and then diluted with $2 \% \mathrm{v} / \mathrm{v}$ nitric acid until their concentration was within the desired concentration range and were used in subsequent analyses. An Agilent Technologies 7500ce 
ICP-mass spectrometry (MS) instrument, equipped with a MicroMist glass concentric nebuliser, and Peltier-cooled, Scott type spray chamber was used.

\section{Results and discussion}

\subsection{The influence of the reducing agent and its molarity}

In the first part of the research, different reducing agents and their molar concentrations were studied for in situ synthesis of $\mathrm{ZnO}$ nanoparticles. The synthesis process consisted of a 30-minute treatment of the fabric in a precursor solution $\left(\mathrm{ZnCl}_{2}\right)$ and a 60-minute treatment after the addition of the reducing agent $\left(0.1 \mathrm{M} \mathrm{Na}_{2} \mathrm{CO}_{3}, 1 \mathrm{M} \mathrm{Na}_{2} \mathrm{CO}_{3}, 0.1 \mathrm{M}\right.$ $\mathrm{KOH}, 1 \mathrm{M} \mathrm{KOH}, 0.1 \mathrm{M} \mathrm{NaOH}, 1 \mathrm{M} \mathrm{NaOH}$ ). After the in situ synthesis, samples were dried for 240 minutes, washed with distilled water, wrung and dried at $100{ }^{\circ} \mathrm{C}$ for 5 minutes. The $0.1 \mathrm{M}$ concentration of all used reducing agents led to the formation of an uneven distribution of $\mathrm{ZnO}$ nanoparticles on the cotton fibres (Figures 1b, 1d, 1f). Here, some larger agglomerates are also noticeable. In the case when $1 \mathrm{M} \mathrm{Na}_{2} \mathrm{CO}_{3}$ was used as the reducing agent, the $\mathrm{ZnO}$ was formed in layers and not as nanoparticles (Figure 1c). Some cracking of the layers is visible. The formation of $\mathrm{ZnO}$ nanoparticles and their relatively good distribution on the cotton fibres was achieved using $1 \mathrm{M} \mathrm{KOH}$ as the reducing agent (Figure 1e). On this sample, only a few agglomerates have formed. Figure $1 \mathrm{~g}$ shows the sample where $1 \mathrm{M} \mathrm{NaOH}$ was used as the reducing agent. Here, evenly distributed $\mathrm{ZnO}$ nanoparticles have completely coated the fibre surface and only a few larger agglomerates are visible.

The SEM images reveal that the choice of reducing agent has an influence on the morphology of the in situ synthesised $\mathrm{ZnO}$ nanoparticles and their distribution on the fibres. Consequently, the UV protection properties of the samples are affected. In Table 1, UPF, transmission of UVA and UVB radiation, a)

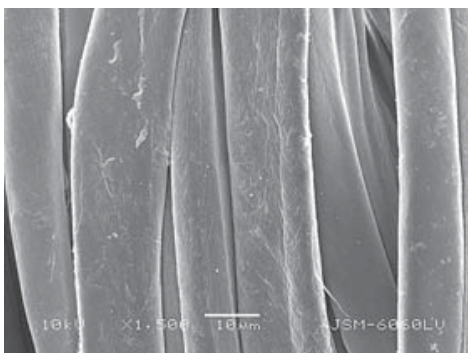

d)

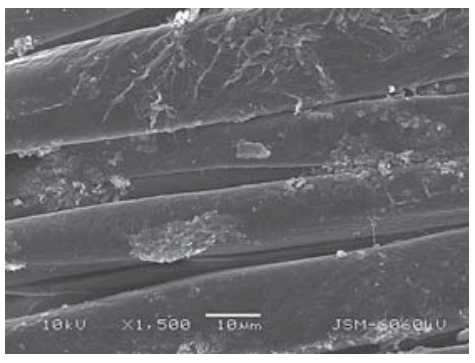

g)

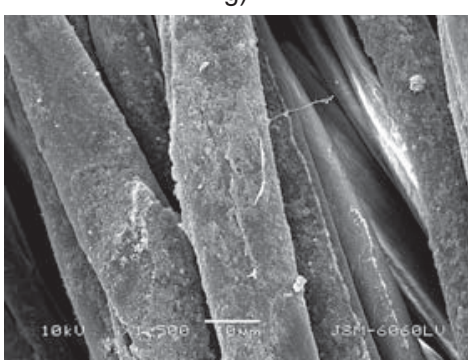

b)

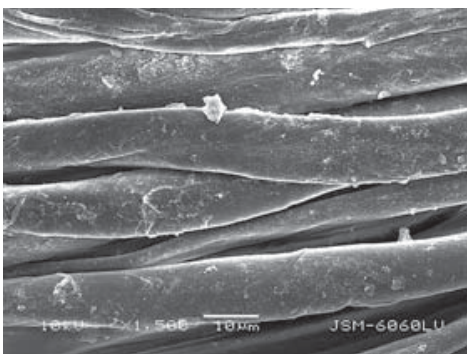

e)

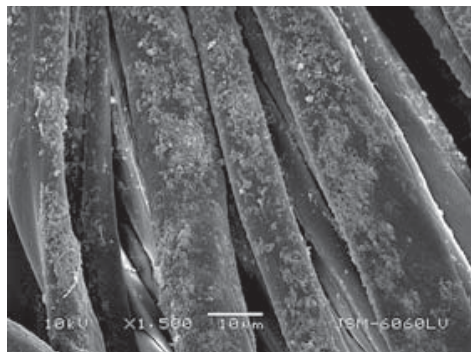

c)

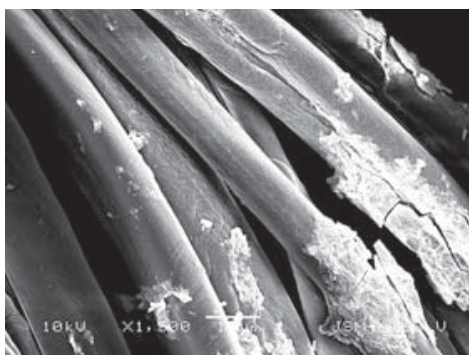

f)

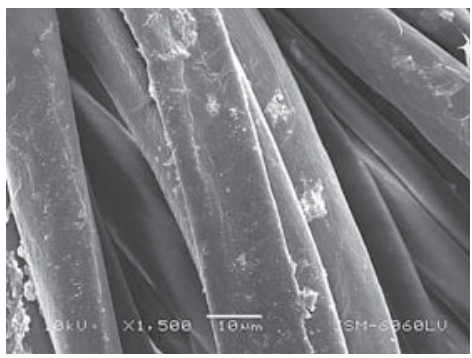

Figure 1: SEM images of a) untreated cotton fabric and cotton fabrics, functionalised with $\mathrm{ZnO}$ nanoparticles and synthesised with b) $0.1 \mathrm{M}$ $\mathrm{Na}_{2} \mathrm{CO}_{3}$, c) $1 \mathrm{M} \mathrm{Na}_{2} \mathrm{CO}_{3}$, d) $0.1 \mathrm{M} \mathrm{KOH}$, e) $\left.1 \mathrm{M} \mathrm{KOH}, f\right) 0.1 \mathrm{M} \mathrm{NaOH}, g$ ) $1 \mathrm{M} \mathrm{NaOH}$ at $1500 x$ magnification 
blocking of UVA and UVB radiation and protection category of the untreated and $\mathrm{ZnO}$ functionalised samples are presented. Untreated cotton has insufficient $\mathrm{UV}$ protection $(\mathrm{UPF}=4.9)$. In situ synthesis of $\mathrm{ZnO}$ when $0.1 \mathrm{M} \mathrm{KOH}, \mathrm{NaOH}$ and both molar concentrations of $\mathrm{Na}_{2} \mathrm{CO}_{3}$ were used as reducing agents does not significantly improve the UV protection of the cotton fabric. The UPF values of these samples remained under a value of 15 ; therefore, the samples do not provide sufficient UV protection according to the AS/NZ standard. High UV protection was achieved on the samples where $1 \mathrm{M} \mathrm{KOH}$ and $\mathrm{NaOH}$ were used as the reducing agents. The highest UPF value was achieved with the $1 \mathrm{M} \mathrm{NaOH}$ reducing agent ( $\mathrm{UPF}=80.2$ ), which places the sample into the excellent UV protection (50+) category. Excellent UV protection was also achieved on the sample where $1 \mathrm{M} \mathrm{KOH}$ was used as the reducing agent. The measured value of UPF was 58.4. Therefore, the results of the UV/Vis spectrophotometric measurements are in accordance with the SEM images. Samples where $\mathrm{ZnO}$ was formed in layers or there was only a small amount of nanoparticles visible on the samples did not provide sufficient UV protection, while the samples where an even distribution of a larger amount of nanoparticles was observed provided excellent UV protection.

From the results of the UV/Vis spectrophotometry and SEM analysis, we assumed that the sample where the $\mathrm{NaOH}$ reducing agent was used for the in situ synthesis of $\mathrm{ZnO}$ nanoparticles had a higher content of nanoparticles than the sample where the $\mathrm{KOH}$ reducing agent was used. With inductively coupled plasma mass spectrometry we confirmed our assumption (Table 2). Sample 1_NaOH with a higher UPF value (80.2), has a higher content of zinc $(710.2 \mathrm{mg} / \mathrm{kg})$ than the sample with a lower UPF value (58.4).

Table 2: Concentration of $Z n(c Z n)$ and UPF value of the samples when $1 \mathrm{M} \mathrm{KOH}$ and $1 \mathrm{M} \mathrm{NaOH}$ were used for the in situ synthesis

\begin{tabular}{|l|c|c|}
\hline \multicolumn{1}{|c|}{ Sample } & $c_{\mathrm{Zn}}[\mathrm{mg} / \mathrm{kg}]$ & UPF \\
\hline 1_KOH & 590.0 & 58.4 \\
\hline 1_NaOH & 710.2 & 80.2 \\
\hline
\end{tabular}

The literature describes that the in situ synthesis of $\mathrm{ZnO}$ nanoparticles on textiles provides good wash fastness [16]. However, our results indicate differently. In Figure 2 the results of the UPF values of washed samples 1_NaOH and 1_KOH are presented. The UPF values of both samples have decreased significantly after the first washing cycle. The UPF value of sample 1_KOH decreased from 58.4 to 10 , and that of sample $1 \_\mathrm{NaOH}$ decreased from 80.2 to 8.8. After five domestic washings, the UPF values of both samples are even lower. Our results indicate that the wash fastness of in situ synthesised $\mathrm{ZnO}$ nanoparticles on cotton is not good.

Table 1: Ultraviolet protection factor (UPF), transmission of UVA and UVB radiation (T(UVA) and T(UVB)), UVA and UVB blocking and protection category of the samples, where type and molar concentration of the reducing agent was changed

\begin{tabular}{|l|c|c|c|c|c|l|}
\hline \multicolumn{1}{|c|}{ Sample } & UPF & $\begin{array}{c}\text { T (UVA) } \\
{[\%]}\end{array}$ & $\begin{array}{c}\text { T (UVB) } \\
{[\%]}\end{array}$ & $\begin{array}{c}\text { UVA } \\
\text { blocking } \\
{[\%]}\end{array}$ & $\begin{array}{c}\text { UVB } \\
\text { blocking } \\
{[\%]}\end{array}$ & $\begin{array}{c}\text { Protection } \\
\text { category }\end{array}$ \\
\hline Untreated & 4.9 & 25.5 & 19.4 & 74.5 & 80.6 & insufficient \\
\hline $0.1 \_\mathrm{Na}_{2} \mathrm{CO}_{3}$ a) & 5.8 & 23.1 & 15.8 & 76.9 & 84.2 & insufficient \\
\hline 1_ $\mathrm{Na}_{2} \mathrm{CO}_{3}$ b) & 6.7 & 21.3 & 13.2 & 78.7 & 86.8 & insufficient \\
\hline $0.1 \_\mathrm{KOH}$ & 6.1 & 22.6 & 15.1 & 77.4 & 84.9 & insufficient \\
\hline 1_KOH & 58.4 & 7.6 & 1.4 & 92.4 & 98.6 & excellent \\
\hline 0.1_NaOH & 5.7 & 23.3 & 16.2 & 76.7 & 83.8 & insufficient \\
\hline 1_NaOH & 80.2 & 7.4 & 0.9 & 92.6 & 99.1 & excellent \\
\hline
\end{tabular}

a) $0.1 \_\mathrm{Na}_{2} \mathrm{CO}_{3}-0.1 \mathrm{M}$ concentration of reducing agent

b) $1 \_\mathrm{Na}_{2} \mathrm{CO}_{3}-1 \mathrm{M}$ concentration of reducing agent 


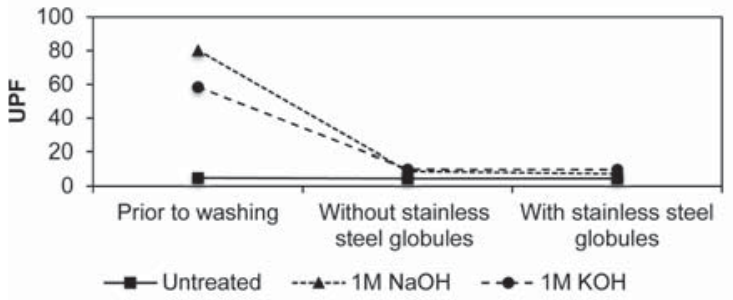

Figure 2: Ultraviolet protection factor (UPF) of the samples after one washing cycle without and with 10 stainless steel globules, which simulates one and five domestic washing cycles

\subsection{The influence of synthesis time and drying time after the synthesis}

To investigate how synthesis time influences the formation of $\mathrm{ZnO}$ nanoparticles and the UV protection of cotton fabric, different time ratios between the treatment of the fabric in precursor $\left(\mathrm{ZnCl}_{2}\right)$ and the treatment after the reducing agent $(1 \mathrm{M}$ $\mathrm{NaOH}$ ) was added were combined, i.e., $10: 10,10$ : $20,10: 30,20: 10,20: 20,30: 10,30: 30$, and 30 : 60 minutes. The measured UPF values of the samples are presented in Table 4. The best UV protection was achieved on a sample where 30 minutes of treatment time in precursor was followed by 60 minutes of treatment time after adding the reducing agent. The measured UPF value of this sample was 80.2, which represents excellent UV protection. The second best UV protection provided by functionalised cotton fabric was achieved with a synthesis time ratio of $30: 30$. UV/Vis spectrophotometric measurements showed that this sample blocks $92.2 \%$ UVA and 97.7\% UVB radiation, and has a UPF value of 39.3. A UPF value 35.5 was achieved by treating the fabric in a precursor for 10 minutes followed by a 30 -minute treatment after the reducing agent was added. The UPF value of 29.2 was achieved on the sample where the treatment to synthesis time ratio was $30: 10$. As shown in Table 4, the samples that were treated for a longer period of time after the reducing agent was added to the reaction bath had higher UPF values than samples that were treated for a longer period of time in the precursor.

The results of the UV/Vis spectrophotometric measurements of the samples where the same synthesis time ratio was used $(30: 30)$ but different drying times were used (from 10 to 240 minutes) are presented in Table 5. Longer drying times did not result in significantly increased UPF values in the functionalised samples. The measured UPF values were in the range of 32 to 39 for all samples. Therefore, the drying time after in situ synthesis does not affect the UPF values of the functionalised samples. However, the drying time did influence the morphology of the $\mathrm{ZnO}$ nanoparticles (Figure 3). The samples presented in Figure 3 are the samples that were dried for the shortest period of time (10 minutes) (Figure 3a) and longest period of time (240 minutes) (Figure 3b). A significant difference in the morphology of the formed $\mathrm{ZnO}$ nanoparticles is noticeable. The nanoparticles were not fully formed into rounded shapes on the sample that was dried for 10 minutes after the in situ synthesis, while the nanoparticles on the sample that was dried for 240 minutes after the in situ synthesis were completely rounded.

Table 4: Ultraviolet protection factor (UPF), transmission of UVA and UVB radiation (T(UVA) and T(UVB)), UVA and UVB blocking and protection category of the samples according to the synthesis time

\begin{tabular}{|c|c|c|c|c|c|l|}
\hline $\begin{array}{c}\text { Synthesis time } \\
\text { ratio [min] }\end{array}$ & UPF & $\begin{array}{c}\text { T (UVA) } \\
{[\%]}\end{array}$ & $\begin{array}{c}\text { T (UVB) } \\
{[\%]}\end{array}$ & $\begin{array}{c}\text { UVA } \\
\text { blocking [\%] }\end{array}$ & $\begin{array}{c}\text { UVB } \\
\text { blocking [\%] }\end{array}$ & $\begin{array}{c}\text { Protection } \\
\text { category }\end{array}$ \\
\hline $10: 10$ & 22.0 & 10.5 & 4.0 & 89.5 & 96.0 & good \\
\hline $10: 20$ & 29.7 & 9.2 & 3.4 & 90.8 & 96.6 & very good \\
\hline $10: 30$ & 35.2 & 8.8 & 3.0 & 91.2 & 97.0 & very good \\
\hline $20: 10$ & 19.7 & 10.8 & 4.4 & 89.2 & 95.6 & good \\
\hline $20: 20$ & 28.7 & 9.1 & 3.0 & 90.9 & 97.0 & very good \\
\hline $30: 10$ & 29.2 & 9.2 & 3.1 & 90.8 & 96.9 & very good \\
\hline $30: 30$ & 39.3 & 7.8 & 2.3 & 92.2 & 97.7 & very good \\
\hline $30: 60$ & 80.2 & 7.4 & 0.9 & 92.6 & 99.1 & excellent \\
\hline
\end{tabular}

a) Time ratio between treatment of fabric in precursor and after adding the reducing agent. 
Table 5: Ultraviolet protection factor (UPF), transmission of UVA and UVB radiation (T(UVA) and T(UVB)), $U V A$ and UVB blocking and protection category of the samples with different drying times

\begin{tabular}{|c|c|c|c|c|c|l|}
\hline $\begin{array}{c}\text { Drying } \\
\text { time [min] }\end{array}$ & UPF & $\begin{array}{c}\text { T (UVA) } \\
{[\%]}\end{array}$ & $\begin{array}{c}\text { T (UVB) } \\
{[\%]}\end{array}$ & $\begin{array}{c}\text { UVA blocking } \\
{[\%]}\end{array}$ & $\begin{array}{c}\text { UVB blocking } \\
{[\%]}\end{array}$ & $\begin{array}{c}\text { Protection } \\
\text { category }\end{array}$ \\
\hline 10 & 34.9 & 9.5 & 2.6 & 90.5 & 97.4 & very good \\
\hline 30 & 36.9 & 9.0 & 3.2 & 91.0 & 96.8 & very good \\
\hline 60 & 32.4 & 9.0 & 2.9 & 91.0 & 97.1 & very good \\
\hline 120 & 39.8 & 8.4 & 2.3 & 91.6 & 97.8 & very good \\
\hline 240 & 39.3 & 7.8 & 2.3 & 92.2 & 97.7 & very good \\
\hline
\end{tabular}

a)

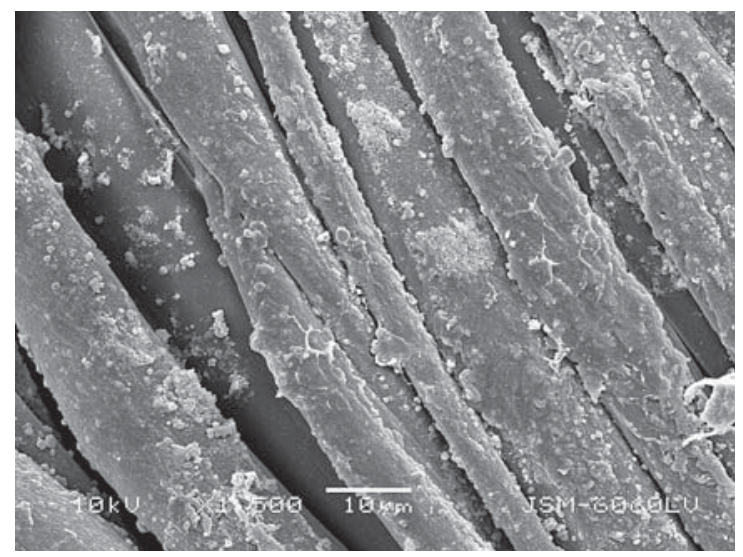

b)

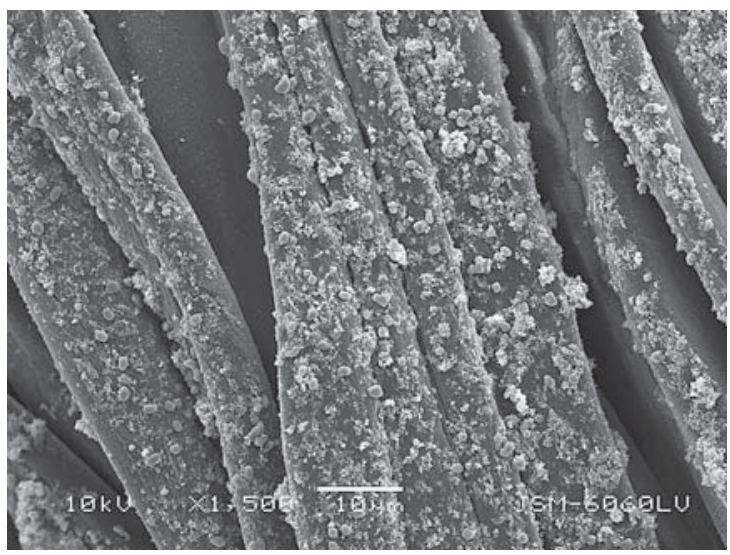

Figure 3: SEM images of the cotton samples with drying time: a) 10 minutes and b) 240 minutes

\section{Conclusion}

The parameters of the in situ synthesis of $\mathrm{ZnO}$ nanoparticles and the UV protection factor of the functionalised fabric were studied. The results show that the highest concentration of $\mathrm{ZnO}$ nanoparticles and their even distribution on the fibres, which results in highest UPF value of the functionalised fabric, is achieved when the in situ synthesis is performed with $1 \mathrm{M} \mathrm{NaOH}$ as a reducing agent. Such a sample provides excellent protection of the skin against UV radiation and could be potentially used for the production of UV protective textiles (i.e., clothes, parasols). The synthesis time ratio crucially affects the formation of $\mathrm{ZnO}$ nanoparticles on the fibre surface and consequently on the UPF value of cotton fabric. Higher UPF values of functionalised cotton fabrics are achieved when the treatment time after adding the reducing agent is prolonged. The drying time after the in situ synthesis does not signif- icantly influence the UPF value of the functionalised cotton fabric, but it does influence the morphology of the formed $\mathrm{ZnO}$ nanoparticles. At a longer drying time, more rounded nanoparticles are formed. The results of this research showed that the in situ synthesis of nanoparticles did not increase the wash fastness of the functionalised cotton fabric. The results of the research have the potential to advance the development of UV protective textiles; however, due to the poor wash fastness, future research has to focus on achieving better adhesion of synthesised nanoparticles on cotton fabric, i.e., by plasma pretreatment of the fabric and/or the use of binders that could form a matrix to entrap the nanoparticles.

\section{Acknowledgement}

This work was financially supported by the Slovenian Research Agency, Slovenia (Program P2-0213 Textiles and Ecology). 


\section{References}

1. KERT, Mateja, JAZBEC, Katja, ČERNE, Lidija, JERMAN, Ivo, GORJANC, Marija. The influence of nano- $\mathrm{ZnO}$ application methods on UV protective properties of cotton. Acta Chimica Slovenica, 2014, 61(3), 587-594.

2. VERBIČ, Anja, STOJKOSKI, Viktor, TOMŠIČ, Brigita, ŠPIČKA, Nina, ŠTULAR, Danaja, GORJANC, Marija, KERT, Mateja, SIMONČIČ, Barbara. Preparation of functional stimuli-responsive polyamide 6 fabric with $\mathrm{ZnO}$ incorporated microgel. Tekstilec, 2018, 61(1), 15-26, doi: 10. 14502/Tekstilec2018.61.15-26.

3. ŠTULAR, Danaja, JERMAN, Ivan, NAGLIČ, Iztok, SIMONČIČ, Barbara, TOMŠIČ, Brigita. Embedment of silver into temperature-and $\mathrm{pH}$ responsive microgel for the development of smart textiles with simultaneous moisture management and controlled antimicrobial activities. Carbohydrate Polymers, 2017, 159, 161-170, doi: 10.1016/j.carbpol.2016.12.030.

4. TOMŠIČ, Brigita, SIMONČIČ, Barbara, OREL, Boris, ČERNE, Lidija, TAVČER, Petra Forte, ZORKO, Mateja, JERMAN, Ivan, VILČNIK, Aljaž, KOVAČ, Janez. Sol-gel coating of cellulose fibres with antimicrobial and repellent properties. Journal of Sol-Gel Science and Technology, 2008, 47(1), 44-57, doi: 10.1007/s10971-0081732-1.

5. IBRAHIM, Nabil A., EL-ZAIRY, E. M., EID, B. M., EMAM, E., BARKAT, S. R.. A new approach for imparting durable multifunctional properties to linen-containing fabrics. Carbohydrate polymers, 2017, 157, 1085-1093, doi: 10.1016/j. carbpol.2016.10.074.

6. PULIT-PROCIAK, Jolanta, CHWASTOWSKI, Jarosław, KUCHARSKI, Arkadiusz, BANACH, Marcin. Functionalization of textiles with silver and zinc oxide nanoparticles. Applied Surface Science, 2016, 385, 543-553, doi: 10.1016/j. apsusc.2016.05.167.

7. KÜÇÜK, Merve, ÖVEÇOĞLU, Mustafa Lütfi. Surface modification and characterization of polyester fabric by coating with low temperature synthesized $\mathrm{ZnO}$ nanorods. Journal of SolGel Science and Technology, 2018, 88(2) 1-14, doi: 10.1007/s10971-018-4817-5.

8. KOŁODZIEJCZAK-RADZIMSKA, Agnieszka, JE -SIONOWSKI, Teofil. Zinc oxide-from synthesis to application: a review. Materials, 2014, 7(4), 2833-2881, doi: 10.3390/ma7042833.

9. WILLANDER, Magnus, YANG, Linquan L., WADEASA, A., ALI, Syed Usman, ASIF, Muhammad H., ZHAO, Qing Xiang,, NUR, Omer. Zinc oxide nanowires: controlled low temperature growth and some electrochemical and optical nano-devices. Journal of Materials Chemistry, 2009, 19(7), 1006-1018, doi: 10. 1039/B816619F.

10. JAZBEC, Katja, ŠALA, Martin, MOZETIČ, Miran, VESEL, Alenka, GORJANC, Marija. Functionalization of cellulose fibres with oxygen plasma and $\mathrm{ZnO}$ nanoparticles for achieving UV protective properties. Journal of Nanomaterials, 2015, 2015, 1-9, doi: 10.1155/2015/346739.

11. GORJANC, Marija, JAZBEC, Katja, ŠALA, Martin, ZAPLOTNIK, Rok, VESEL, Alenka, MOZETIČ, Miran. Creating cellulose fibres with excellent UV protective properties using moist $\mathrm{CF}_{4}$ plasma and $\mathrm{ZnO}$ nanoparticles. Cellulose, 2014, 21(4), 3007-3021, doi: 10.1007/ s10570-014-0284-5.

12. PRIMC, Gregor, TOMŠIČ, Brigita, VESEL, Alenka, MOZETIČ, Miran, ERCEGOVIĆ RAŽIĆ, Sanja, GORJANC, Marija. Biodegradability of oxygen-plasma treated cellulose textile functionalized with $\mathrm{ZnO}$ nanoparticles as antibacterial treatment. Journal of Physics. D, Applied physics, 2016, 49(32), 324002-1-32400210, doi: 10.1088/0022-3727/49/32/324002.

13. SHAO, Dongfeng, GAO, Yan, CAO, Kan, WEI, Qufu. Rapid surface functionalization of cotton fabrics by modified hydrothermal synthesis of $\mathrm{ZnO}$. The Journal of the Textile Institute, 2017, 108(8), 1391-1397, doi: 10.1080/00405000.2016. 1254581.

14. MONTAZER, Majid, MAALI AMIRI Morteza, MOHAMMAD ALI MALEK, Reza. In situ synthesis and characterization of nano $\mathrm{ZnO}$ on wool: Influence of nano photo reactor on wool properties. Photochemistry and Photobiology, 2013, 89(5), 1057-1063, doi: 10.1111/php. 12090.

15. BORDA D' AGUA, Raquel, BRANQUINHO, Rita, DUARTE, Maria Paula, MAURICIO, Elisabete, FERNANDO, Ana Luisa, MARTINS, Rodrigo, FORTUNATO, Elvira. Efficient coverage of $\mathrm{ZnO}$ nanoparticles on cotton fibres for antibacterial finishing using a rapid and low cost in situ synthesis. New Journal of Chemistry, 2018, 42, 1052-1060, doi: 10.1039/c7nj03418k. 
16. ARPUTHARAJ, Anthonysamy, NADANATHANGAM, Vigneshwaran, SHUKLA, Sanjeev R. A simple and efficient protocol to develop durable multifunctional property to cellulosic materials using in situ generated nano-ZnO. Cellulose, 2017, 24(8), 3399-3410, doi: 10.1007/ s10570-017-1335-5.

17. GHAYEMPOUR, Soraya, MONTAZER, Majid. Ultrasound irradiation based in-situ synthesis of star-like Tragacanth gum/zinc oxide nanoparticles on cotton fabric. Ultrasonics Sonochemistry, 2017, 34, 458-465, doi: 10.1016/j. ultsonch.2016.06.019.

18. PRASAD, Virendra, ARPUTHARAJ, Anthonysamy, BHARIMALLA, Ashok K., PATIL, Prashant G., VIGNESHWARAN, Nadanathanga. Durable multifunctional finishing of cotton fabrics by in situ synthesis of nano-ZnO. Applied Surface Science, 2016, 390, 936-940, doi: 10.1016/j.apsusc.2016.08.155.

19. KHOSRAVIAN, Shokoufeh, MONTAZER, Majid, MOHAMMAD ALI MALEK, Reza, HARIFI, Tina. In situ synthesis of nano $\mathrm{ZnO}$ on starch sized cotton introducing nano photo active fabric optimized with response surface methodology. Carbohydrate Polymers, 2015, 132, 126-133, doi: 10.1016/j.carbpol.2015.05.085.

20. WASLY, Hamdy Sayed, ABD EL-SADEK, Mahmoud Sayed, HENINI, Mohamed. Influence of reaction time and synthesis temperature on the physical properties of $\mathrm{ZnO}$ nanoparticles synthesized by the hydrothermal method. Applied Physics A, 2018, 124(76), 1-12, doi: 10.1007/ s00339-017-1482-4.

21. SHAHEEN, Tharwat I., EL-NAGGAR, Mehrez E., ABDELGAWAD, Abdelrahman M., HEBEISH, Ali. Durable antibacterial and UV protections of in situ synthesized zinc oxide nanoparticles onto cotton fabrics. International Journal of Biological Macromolecules, 2016, 83, 426-432, doi: 10.1016/j.ijbiomac. 2015.11.003.

22. EL-NAGGAR, Mehrez E., SHAARAWY, Sabry M., HEBEISH, Ali Ali. Multifunctional properties of cotton fabrics coated with in situ synthesis of zinc oxide nanoparticles capped with date seed extract. Carbohydrate Polymers, 2018, 181, 307-316, doi: 10.1016/j.carbpol. 2017.10.074.

23. ZHANG, Guangyu, MORIKAWA, Hideaki, CHEN, Yuyue, MIURA, Mikihiko. In-situ synthesis of $\mathrm{ZnO}$ nanoparticles on bamboo pulp fabric. Materials Letters, 2013, 97, 184-186, doi: 10.1016/j.matlet.2013.01.096.

24. AS/NZS 4399:1996 Australian/New Zealand Standard. Sun protective clothing - evaluation and classification. Homebush : Standards Australia, 1996. 